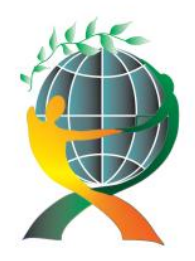

\author{
(online) $=$ ISSN $2285-3642$ \\ ISSN-L = $2285-3642$ \\ Journal of Economic Development, Environment and People \\ Volume 1, Issue 3, 2012 \\ URL: http://jedep.spiruharet.ro \\ e-mail: office jedep@spiruharet.ro
}

\title{
Urban Development Toolkit for Climate Change: Critical Review of State Intervention in Praxis
}

\author{
Vladimir Mihajlov, MSci \\ Faculty of Architecture, \\ Bulevar kralja Aleksandra 73/II, Belgrade \\ E-mail: mailto:mihajlovvladimir@yahoo.com
}

\begin{abstract}
This paper aims to review the various forms of state intervention in urban planning, and its purpose is to reconsider guidelines for solving problems in cities, caused by climate change.

After World War II, urban planning was guided by centralized state management, in the scope of progress and social justice. State intervention was recognized as an instrument for creating new models of the city spatial organization. However, because of the new market conditions arising, the policies about Urban Development came in the focus again, in order to control global influences, mainly climate change (the costs of construction, environmental pollution and hazards). It is therefore necessary to return again to the public intervention in urban planning. This will not be easy, because it has to be consistent with democratic freedoms; some of them should be strengthened, and some limited to ameliorate the effects of climate change.

In conclusion, the set of general guidelines is expected, in order to translate the policy measures for climate change mitigation, into the instruments urban development is controlled by. Therefore, the changes in defining of building codes are expected, as well as the standards for energy conservation and land-use control (zoning, taxes and urban regulations, etc.).
\end{abstract}

Keywords: Climate Change Mitigation, Regulation, State Intervention, Urban Planning

JEL Codes: Q54, 02, R 58 


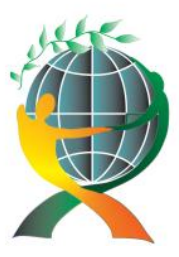

\author{
(online) $=$ ISSN $2285-3642$ \\ ISSN-L = $2285-3642$ \\ Journal of Economic Development, Environment and People \\ Volume 1, Issue 3, 2012 \\ URL: http://jedep.spiruharet.ro \\ e-mail: office jedep@spiruharet.ro
}

\title{
1. Introduction: the background of the research and its aims
}

This paper seeks to address the challenge on regulation of urban development in the context of climate change. Climate change, nowadays, is according to some referent authors, the ultimate risk multiplier (Roaf, Crichton \& Nicol, 2005). Especially, the region of Southern Europe is ranked in the IPCC report as highly vulnerable to climate change ${ }^{1}$. The biggest economic damage, partly in Serbia, may be caused by the drought, floods, storms, landslides, water erosion, and in recent years increased frequency of occurrence of heat waves and forest fires. Temperature trend in Serbia in the period 1950-2008 is also marked upward (about $1.20^{\circ} \mathrm{C}$ ), as the constant decrease in annual rainfall (about $120 \mathrm{~mm}$ ) was recorded. In the Research work named "Changes of some climatic parameters in the urban areas of the Republic of Serbia" is concluded that "large urban areas in Serbia have the effect of amplification of extremes - drought in the wider territory in the cities even drier and those with increased rainfall also tend to extreme values."(Jovanovic, Savic \& Despotovic, 2009).
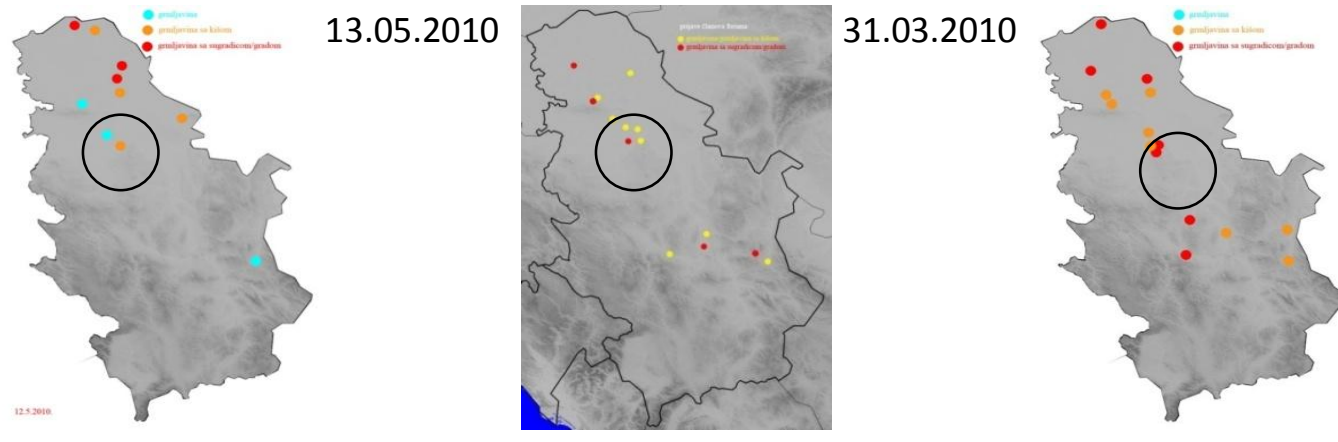

06.05.2010

Fig. 1: Climate change and evaluating the quality of urban settlements in Serbia: distribution of natural disasters during the year 2010. Source: "Changes of some climatic parameters in the urban areas of the Republic of Serbia" (Jovanovic, Savic \& Despotovic, 2009)

\footnotetext{
${ }^{1}$ IPPC report AR4 (2007)
} 


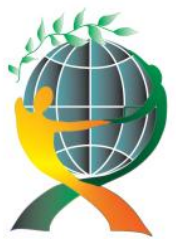

\author{
(online) $=$ ISSN $2285-3642$ \\ ISSN-L = $2285-3642$ \\ Journal of Economic Development, Environment and People \\ Volume 1, Issue 3, 2012 \\ URL: http://jedep.spiruharet.ro \\ e-mail: office jedep@spiruharet.ro
}

Problems mentioned may produce even more unfavourable effects in cities in Serbia, and would be manifested primarily through the increase of water stress due to lower availability of potable water; increasing the frequency and intensity of torrential floods and landslides, water quality deterioration in the conditions and more frequent dry periods or floods, increase evaporation, reduced rainfall, runoff and river water level and shifting climatic zones to the north. Those are the problems which will have to be treated and solved in the very close future.

In the period after World War II, urban development control in Serbia mainly meant centralized management of the state in the interest of general economic progress and social justice, but the urban development was not focused to the environmental problems. In urban planning during the first half of $20^{\text {th }}$ century, the state intervention and nationalization of industry was mainly recognized by the attempts to create new garden cities ${ }^{2}$. Ethic premises of urban development control were healthy environment and sustainable development only, not economy and efficiency. However, incoming critics about the state intervention, such as ones from economist Friedrich Von Hayek, argue that only the market may define pricing decisions in the economy, including the cost of pollution protection, air emissions, and other causes of climate change.

Nowadays, the need to reconsider and raise again the public intervention in urban planning is manifested increasingly, mainly because of costs and benefits of stakeholders, as well as because of climate change influences. Public intervention in urban development will not be easy to realize, because it has to be consistent with democratic freedoms; some of them should be strengthened, and some limited to ameliorate the effects of climate change. The set of general guidelines is expected, in order to run up the policy measures for climate change mitigation, into the instruments urban development is controlled by. Therefore, the changes in defining of building codes are expected, as well as the standards for energy conservation and land-use control.

Observing the problems of climate change, the expected goals in state intervention for urban development in Serbia may be ${ }^{3}$ :

- The application of standard methods and guidelines based on climate change mitigation and adaptation (use of conventions, standards and best practices and experiences in the EU and other developed countries)

- Existing a special state program for treating the problems of spatial development caused by climate change; the concept which includes creative instruments, measures and policies of coordination and participation the competent institutions, as well as local communities.

\footnotetext{
2 “Archipelagos of settlements in the sea of green", an idea from Belgrade Master Plan 1974

${ }^{3}$ The Draft of Spatial Plan of the Republic of Serbia 2014 -2021, pp 100
} 


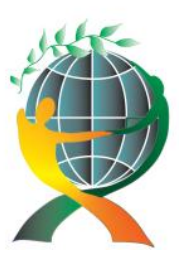

\author{
(online) $=$ ISSN $2285-3642$ \\ ISSN-L = $2285-3642$ \\ Journal of Economic Development, Environment and People \\ Volume 1, Issue 3, 2012 \\ URL: http://jedep.spiruharet.ro \\ e-mail: office jedep@spiruharet.ro
}

\title{
2. Theoretical background of principles and methods of urban development control for climate change
}

Adaptation to climate change is, according to Gidens, "The ability of the environment to support change, without formation of hazardous situations" (Gidens, 2008). From the social point of view, the discussions about the climate change on adaptation and mitigation has arisen to estimate and resolve conflicts between the current neoliberal and green politics, as the ultimate need to create "low carbon, positive model of society" in the future.

Lewis Mumford indicated that discovery of the cities' history has its significance and linkage to gravitating agricultural land (Mumford, 1961). Irrigation systems in Egypt are very important to understand the principles for adaptation to climatic conditions. As of the first Paleolithic - Neolithic unification, and the first hint of this form of human community, Mumford follows the establishment and development of urban projects, as well as the transformation, the emergence of megalopolises and policies for various reasons, because of climate change.

Hence the idea to examine the changes in construction, building codes, standards for energy savings and control of land use. That's the reason fundamental studies in planning an econometrics are arisen again, in order to predict the costs and investments of urban development for climate change, to trade greenhouse gas emissions vs. taxation broadcasters ${ }^{4}$. Measures to be implemented are also increased water saving, more frequent rotation of crops, floating gardens (aquatic weeds on which crops can be grown), better thermal insulation of buildings, using materials resistant to floods and storms.

Adaptation of the economy in building the cities is the most important one: the change of price of real estate and commodities, and the amount of insurance to protect from hazards and natural disasters.

The instruments of urban development control in democratic societies

In the 20th century, economist Keynes WAS influenced by his doctrine on state intervention methods (Keynes, 1933). It leaded to the development of public services and public sector in the industrialized countries of Europe and North America. The goal was to intervene at locations where there is no strategic interest of the state, or local community interests, in order to realize a project / public realm (development management, public goods, redistribution of resources ...)

\footnotetext{
${ }^{4}$ Every resident would be determined by the annual volume of gas in the energy consumption in households, work and travel. By unused quotas actors could trade
} 


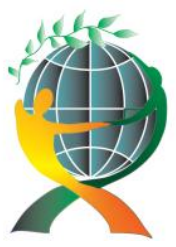

\author{
(online) $=$ ISSN $2285-3642$ \\ ISSN-L = $2285-3642$ \\ Journal of Economic Development, Environment and People \\ Volume 1, Issue 3, 2012 \\ URL: http://jedep.spiruharet.ro \\ e-mail: office jedep@spiruharet.ro
}

In order to reduce the effects of climate change, main government measures in modern societies are focused on: (Gidens, 2008: 113)

1. Problem solving climate change and management of energy risks.

2. Work on economic and political rapprochement. Politics determines the courses of action; the economy provides means to an end.

3. Intervention in markets to the institutionalization of the principle of "polluter pays"

4. Opposition to the interests of investors that block the initiative to solve problems caused by climate change.

5. Maintenance problems climate change at the centre of attention in the media

The following measures are of the most importance in the context of climate change mitigation in urban development:

6. Creation of economic and fiscal environment for the transition to low carbon economy

7. Devising measures to adapt to new climate change

8. Merging of local, regional, national and global aspects of policy relating to climate change.

There are several main changes in the applying methodology of regulation of urban development for climate change in Europe, started in the second half of the 20th century:

1. New, "neoliberal" understanding and expanding the concept of state interventions, to the question of who provides / finances and determines the modes of use of public realm

2. The European Commission Directive 2002/91/EC, adopted in December 2002, designed to result in savings of 45 million tones of $\mathrm{CO} 2$ by 2010 , requires that member states

3. Applying a general framework for calculating the energy performance of buildings.

4. Applying minimum standards of performance for all new buildings.

5. Applying minimum standards of performance for existing buildings over $1000 \mathrm{~m} 2$ that are subject to major renovation.

6. Ensuring that heating systems and air conditioning are inspected regularly.

7. Ensuring that when a building changes occupants an energy performance certificate is made available and displayed in all public buildings plus those visited by the public

\title{
2.1. Several basic "packages" of the urban development toolkit for climate change
}




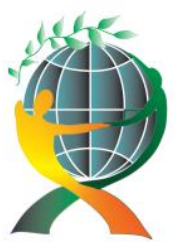

\author{
(online) $=$ ISSN $2285-3642$ \\ ISSN-L = $2285-3642$ \\ Journal of Economic Development, Environment and People \\ Volume 1, Issue 3, 2012 \\ URL: http://jedep.spiruharet.ro \\ e-mail: office jedep@spiruharet.ro
}

Land policy: Restriction of choice to make a purchase contract for urban land. The state is treated as an equal side to a contract of sale of land (the effects of land transactions that cause negative externalities climate change are controlled). Certain activities are restricted and obligations to protect the local community are imposed, and the investor a guaranteed income is considered too.

Limitation of private-property rights: Provides an optimal and appropriate allocation of property rights. Authorities in some countries of Western Europe and the United States purchase the land and then determine the conditions of its use (the assumption is the existence of the State Funds).

Fiscal (tax) policy: Corrective taxes, according to the English economist Pigou (A.C. Pigou, 1920). They can be applied in order to stimulate or sanction indifferent user behavior (unused capital stock tax, tax revenues on a per acre basis (in the USA)), which is charged the separate amount for each annuity zone. Urban planning takes part in forming of the tax system, with the aim to mitigate and adapt the cities to climate change.

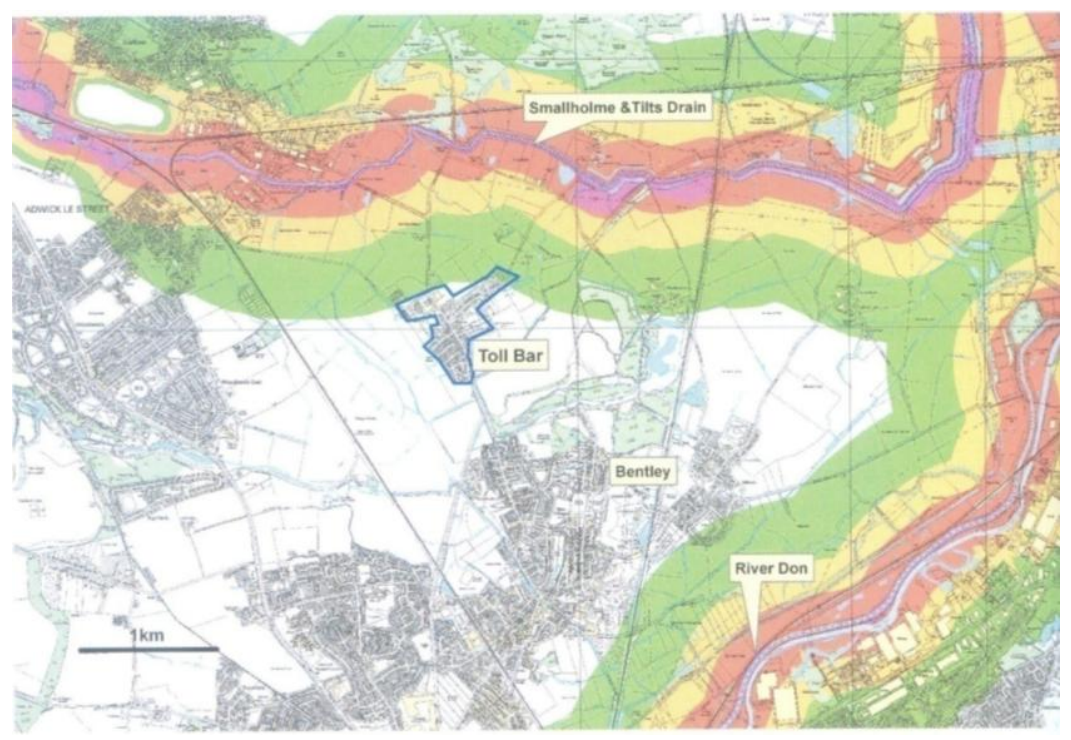

Fig. 2: Map of the tax zones in Bentley area, showing the different levels of hazard caused by climate change. This map is currently used by insurance companies. Source: Roaf Crichton \& Nicol (2006) ADAPTING BUILDINGS AND CITIES FOR CLIMATE CHANGE: A 21st century survival guide. Burlington: Architectural Press 


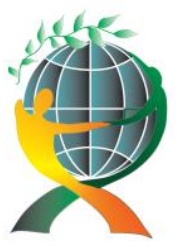

\author{
(online) $=$ ISSN $2285-3642$ \\ ISSN-L = $2285-3642$ \\ Journal of Economic Development, Environment and People \\ Volume 1, Issue 3, 2012 \\ URL: http://jedep.spiruharet.ro \\ e-mail: office jedep@spiruharet.ro
}

State subsidies are determined by the difference between marginal social benefits of urban public goods and the marginal private benefit of the companies (investors). Many countries have made a shift in energy policy, and instead of relying on oil, have switched to nuclear, hydroelectric and energy from biomass. Tax policy is moving in the direction of defining compensation due to greenhouse gas emissions (in Sweden even in early eighties of the twentieth century). In Denmark, the policies of mitigation and adaptation is directed to the subsidy of small biomass power plants in homes, the development of "smart grids" (a decrease of state support measures referred to occurred when the centre - right government was elected 2007). In Serbia, The energy potential of small urban and rural settlements in the region of Vojvodina has been explored by Ivan Simic, from the Faculty of Architecture in Belgrade (Simic, 2011) $)^{5}$

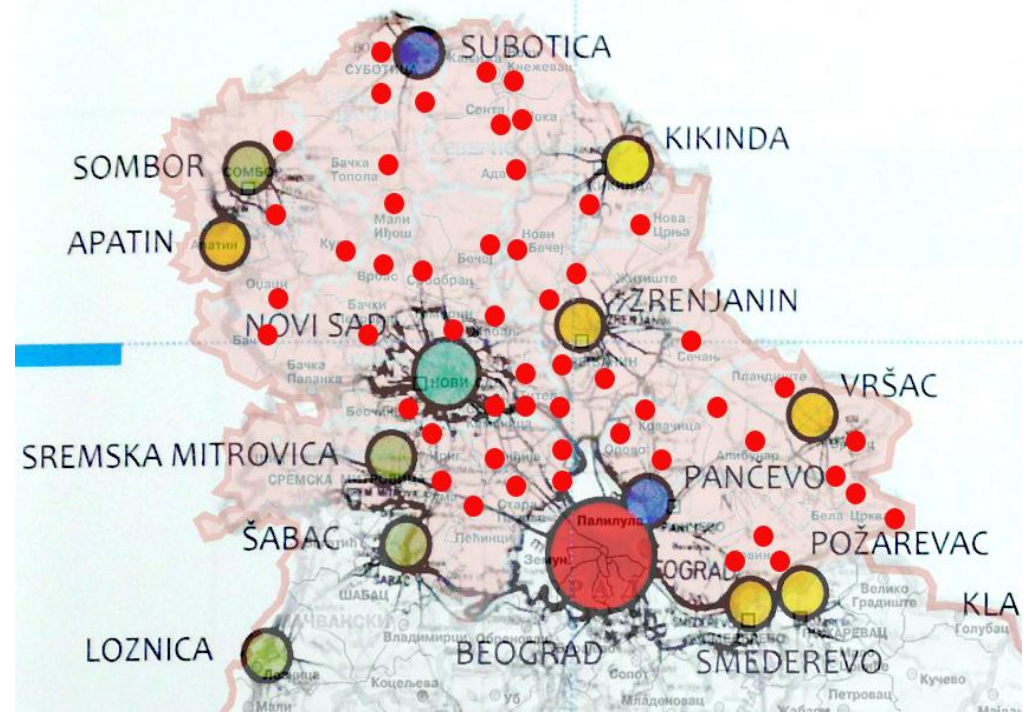

Fig 3: The network of cities "developing engines" and supportive network of small settlements in Vojvodina, Serbia. Source: Simic, I: URBAN BATTERIES - The energy potential of small urban and rural settlements in the region of Vojvodina, IAS-STS Conference 2011, Graz

${ }^{5}$ Simic, I: URBAN BATTERIES - The energy potential of small urban and rural settlements in the region of Vojvodina, IAS-STS Conference 2011, Graz 


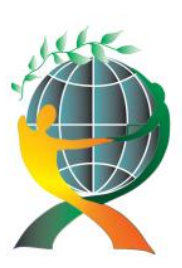

$$
\begin{gathered}
\text { (online) }=\text { ISSN } 2285-3642 \\
\text { ISSN-L }=2285-3642
\end{gathered}
$$

Journal of Economic Development, Environment and People

Volume 1, Issue 3, 2012

URL: http://jedep.spiruharet.ro

e-mail: office jedep@spiruharet.ro
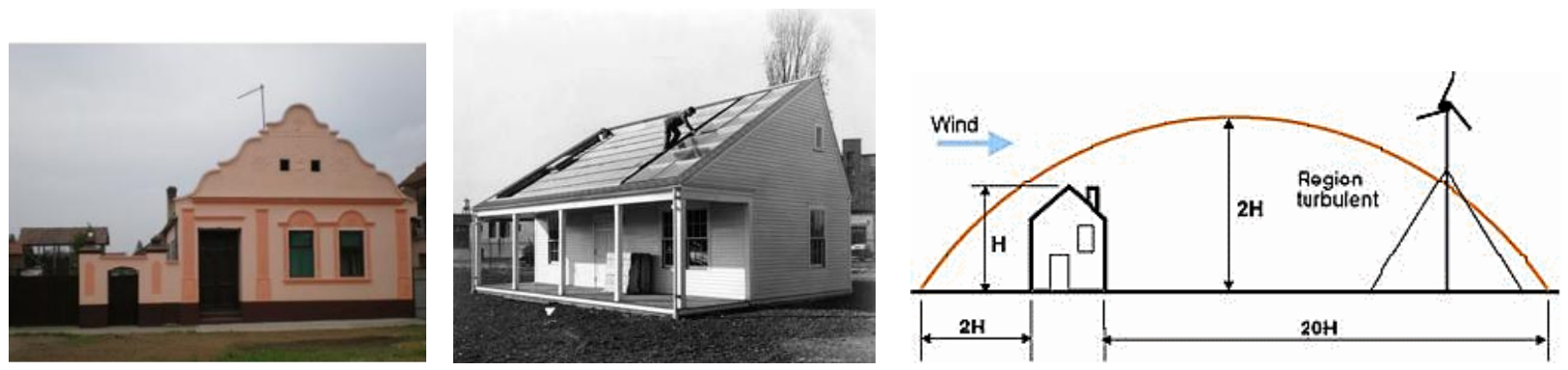

Fig. 4: The concept of urban batteries in Vojvodina. The whole longitudinal side of a housing lot is always facing the sun. Housing lots have appropriate spatial and functional configuration for instaling small wind turbines. Source: Simic, I: URBAN BATTERIES - The energy potential of small urban and rural settlements in the region of Vojvodina, IAS-STS

Conference 2011, Graz

Transferable permissions: The idea that the "polluter should pay" is more easily accepted than other ideas in order to mitigate the effects of climate change. The amount of tax is related to climate change effects and greenhouse gas emissions market of greenhouse gases (market transferable permits).

The United Nations Framework Convention on Climate Change (UNFCCC) and the Kyoto Protocol and emerging greenhouse gas emissions trading schemes are based on calculations of the tonnages of each greenhouse gas (CO2, CH4, N2O, HFCs, PFCs, SF6). National inventories of greenhouse gas emissions are calculated and reported for UNFCCC compliance (and for future compliance with the Kyoto Protocol if it enters into force). Each metric tonne of non- $\mathrm{CO} 2$ gas is converted to $\mathrm{CO} 2$ equivalents using a global warming potential number. Air conditioned buildings in cities use significantly more energy to operate than the naturally ventilated ones. The following figure shows the building types and their annual carbon emissions. 


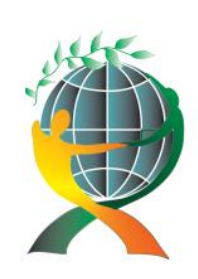

$$
\begin{gathered}
\text { (online) }=\text { ISSN } 2285-3642 \\
\text { ISSN-L }=2285-3642
\end{gathered}
$$

Journal of Economic Development, Environment and People

Volume 1, Issue 3, 2012

URL: http://jedep.spiruharet.ro

e-mail: office jedep@spiruharet.ro

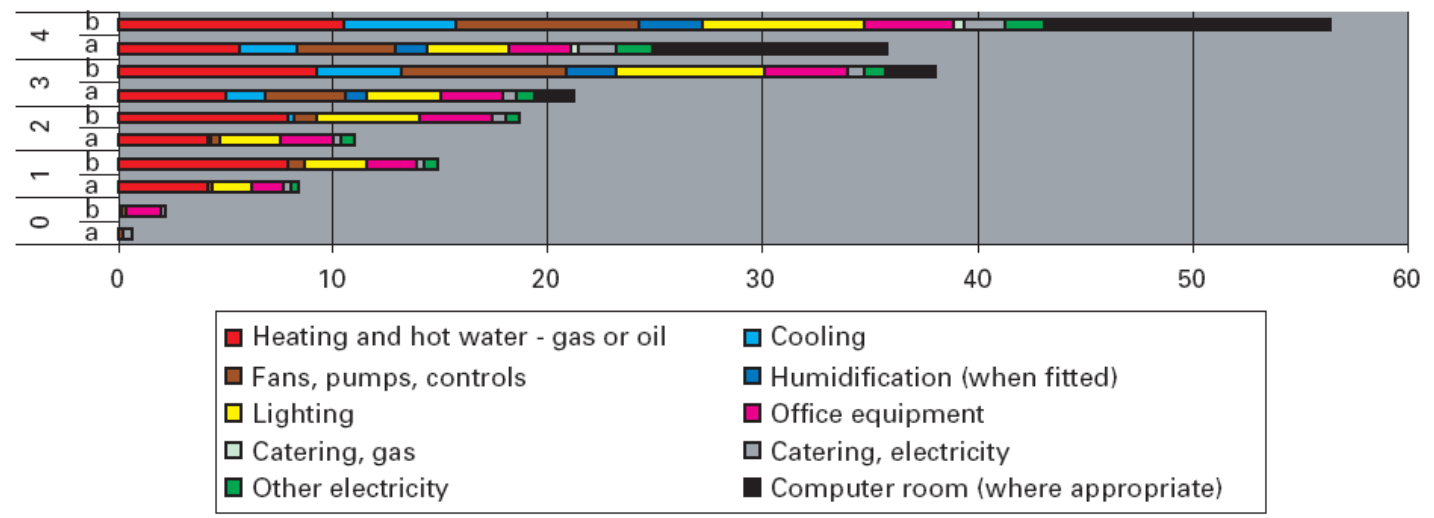

Fig. 3: The building types and their annual carbon emissions. Type 1: traditional office building; type 2: open plan naturally ventilated building; type 3: air conditioned office building. Source: Roaf Crichton \& Nicol (2006) ADAPTING

BUILDINGS AND CITIES FOR CLIMATE CHANGE: A 21st century survival guide. Burlington: Architectural Press

Planning scenarios: The possibility of using methods in the preparation of scenarios realize urban planning in a systematic and better assuming the activities to be supported, activities that must be avoided, as well as possible consequences of decisions to the activities / stakeholders.

Alternative scenarios (preliminary alternatives) are used as means to enable preparing decisions concerning the planning solutions. It includes the following essential items (Vujošević, 2004):

1. Performing consequences and risks in their implementation

2. Appropriate analytical insight into the expectations of various stakeholders

3. Focusing on the key problems / issues / aspects

4. Reduce the possibility of manipulation in the use of expert knowledge or information

5. Mapping the costs and benefits of various options

6. Reliable insight into the scale of preferences and patterns of behavior / response of actors and drawing conclusions in the direction of possible means of implementation;

7. Improving conditions for the application of compromise and consensus in resolving conflicts

Public-private partnerships: "The contributions of public-private partnerships, is understood as a specific type of networked climate governance, to effective and legitimate climate governance. The appraisal of networked governance in the climate change arena is based on their potential contribution to effective climate change mitigation and adaptation" (Dryzek, 1997). The main idea of this partnership is to share the risk when investing in projects that are unprofitable for the private sector (payback period is longer than 10 


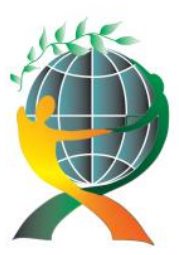

\author{
(online) $=$ ISSN $2285-3642$ \\ ISSN-L = $2285-3642$ \\ Journal of Economic Development, Environment and People \\ Volume 1, Issue 3, 2012 \\ URL: http://jedep.spiruharet.ro \\ e-mail: office jedep@spiruharet.ro
}

years). Condition for establishing a partnership of private and public sectors in the implementation of a public good refers to the exercise of appropriate combinations of purpose / activities, within a specific structure or location of one of the important issues is to create the best conditions (distribution) of investment and profit by Pareto principle. John Dryzek considers eco-technological modernization as the "partnership in which governments, companies, moderate defenders of the environment and scientists collaborate on the adaptation of capitalist political economy of environmentally friendly attitudes." (Dryzek, 1997)

\title{
2.2. Supporting the city development by urban plans and projects
}

The multifold space planning problems in the context of climate change adaptation appears in praxis. The concentration and compaction of high rise buildings permits intensive land use, but causes population over-crowding in localities, at certain times of the day/week. This can result in drastic effects on open areas, streets and parks, and places excessive strain on the existing infrastructure, such as parking, roads, transport, sewerage, water and energy.

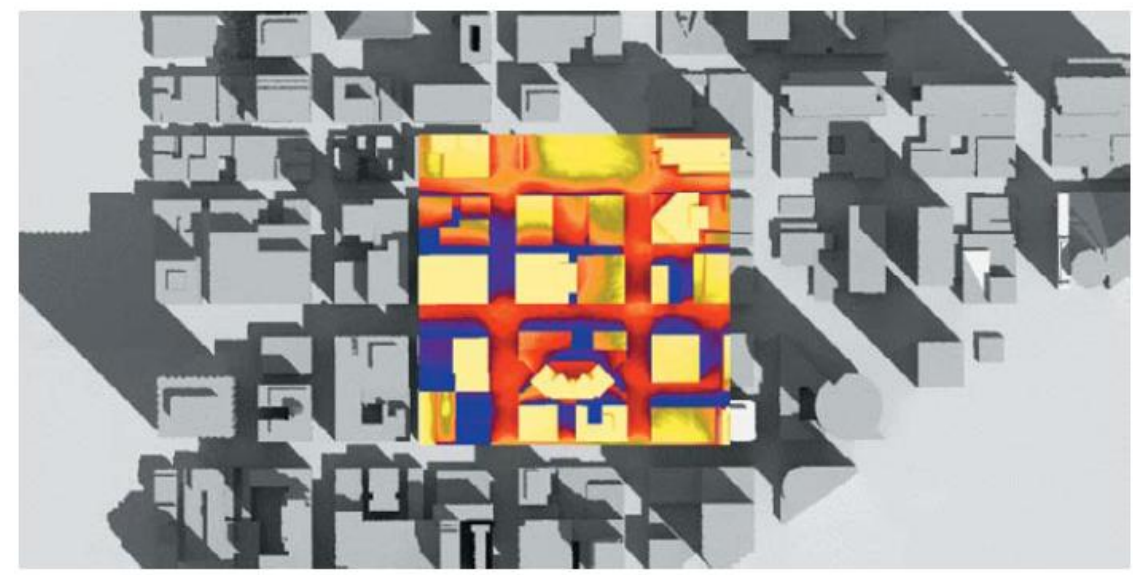

Fig 4: Simulation of an aerial view of San Francisco, showing the surfaces that get most solar gain over a year and shadows that buildings of different shapes and heights cast across an area of the city. Source: John Mardaljevich, Institute for energy and Sustainable Development, De Monfort University, Denmark. www.iesd.dmu.ac.dk

Therefore, the following objectives in urban planning appear, in order to prevent the harmful effects of climate change: 


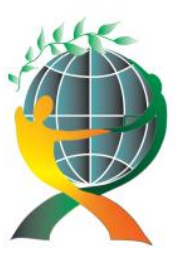

\author{
(online) $=$ ISSN $2285-3642$ \\ ISSN-L = $2285-3642$ \\ Journal of Economic Development, Environment and People \\ Volume 1, Issue 3, 2012
}

URL: http://jedep.spiruharet.ro

e-mail: office jedep@spiruharet.ro

1. Construction of bypasses - development of an efficient traffic (pedestrian connections, mass transportation systems)

2. Reclamation mines and flooded areas (decontamination of terrain, building dams)

3. Dislocation of industrial plants

4. Planting belts of greenery and lifting technical barriers

5. The development of "clean" system of heating and energy networks

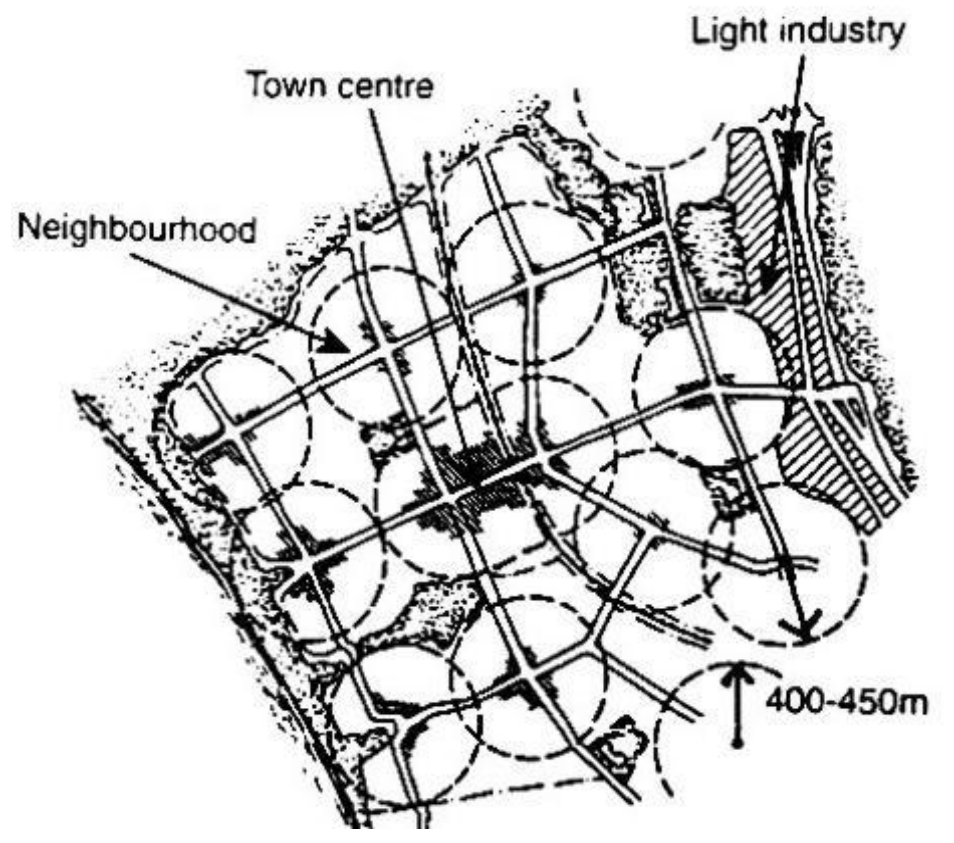

Fig. 5: Graphic scheme of urban parameters for climate change mitigation and adaptation - spatial distribution: pedestrian distances (neighboUrhood - up to 500m), integrated (mixed functions), building density index (i) $=0.5-1$, occupancy percentage $(Z)=\max 20 \%$, number of floors $(S) \max =P+1$. Source: Author

A high rise building usually consists of a shaft and elevators surrounded by living units on each storey. The properties of openings in the south (sun: solar gain) and north (cold wind: infiltration) and the very limited opportunities for the floor plans, with restricted walk distances to fire exits and access shafts, drastically reduces the organizational possibilities of the plan. 


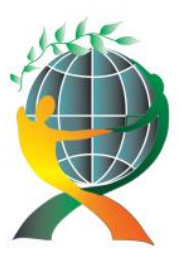

\author{
(online) $=$ ISSN $2285-3642$ \\ ISSN-L = $2285-3642$ \\ Journal of Economic Development, Environment and People \\ Volume 1, Issue 3, 2012 \\ URL: http://jedep.spiruharet.ro \\ e-mail: office jedep@spiruharet.ro
}

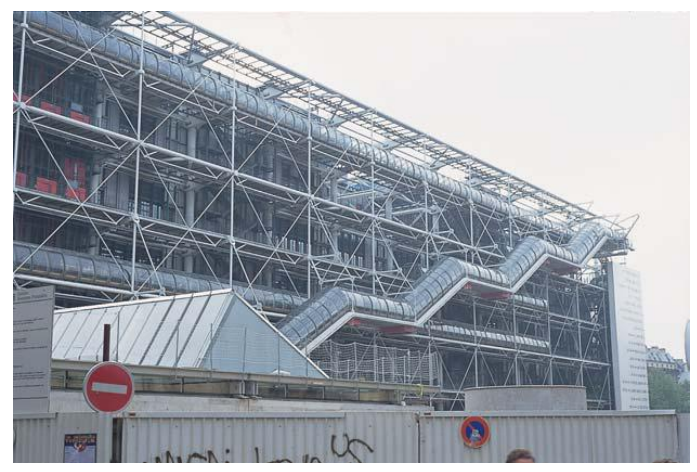

Fig. 6: The Pompidou Centre in Paris, designed by Renzo Piano, Richard Rogers and Gianfranco Franchini, 1977 nonresilient building for climate change. In 1996, the building was closed for four years for the total refurbishment, for which the final bill was a further 576 million francs. Source: $\underline{\text { www.centrepompidou.fr }}$

Considering problems mentioned above, influential parameters for planning are as follows:

1. Construction rules, which oblige the establishment of open space

2. Rationalization of land use, through a redefinition of purpose incompatible with the environment

3. Commitment to the protection of sites with distinct identity

4. Preserve the network of social groups in the community

5. Enhance the network of public services in a residential zone

6. Definition of annuity zone in the city, with different taxes for each zone

7. Improving urban design commitment to the construction of attractive urban rappers and dominant, as a

driver of activity in an open city space

8. Reconstruction and improvement of transportation and utility infrastructure 


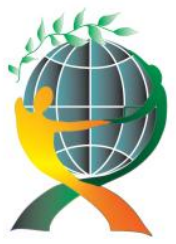

\author{
(online) $=$ ISSN $2285-3642$ \\ ISSN-L = $2285-3642$ \\ Journal of Economic Development, Environment and People \\ Volume 1, Issue 3, 2012
}

URL: http://jedep.spiruharet.ro

e-mail: office jedep@spiruharet.ro

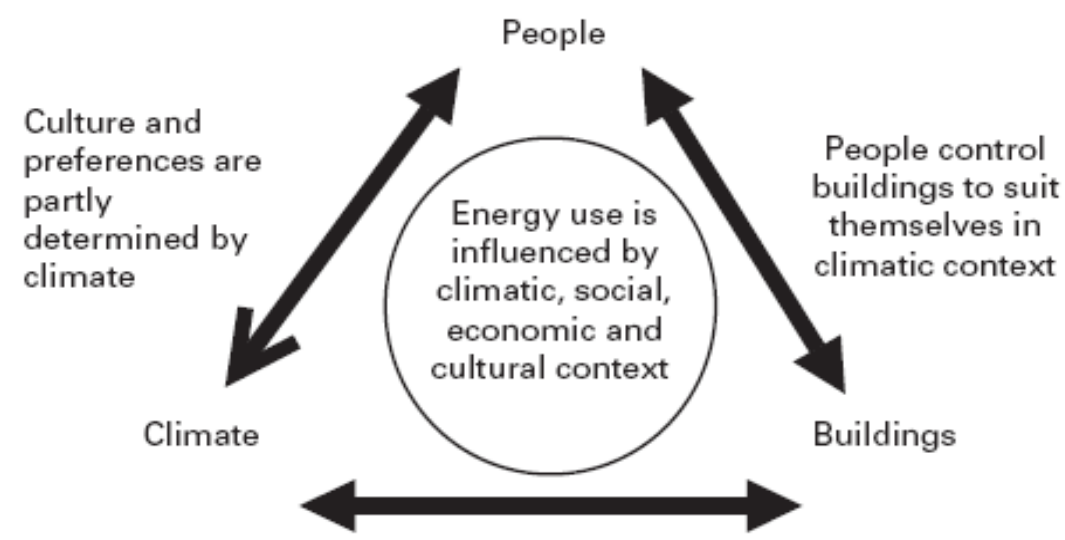

Building ameliorates climate within traditionally occupied settlements to suit occupants and provide comfort within cultural norms

Fig. 7: The traditional three-way interaction between climate, stakeholders, and urban spaces, that didactes our energy needs. Source: Roaf, Crichton \& Nicol (2006) ADAPTING BUILDINGS AND CITIES FOR CLIMATE CHANGE: A 21st century survival guide. Burlington: Architectural Press

This followed by the questions: who will pay the expenses and what is their price? Is it possible to use existing infrastructure (social, economic, built)? Is it possible to modify built environment (to establish the different regimes and ways of organizing its work), in order to come up with a solution regarding the climate change in cities?

In the UK will be built 10 settlements by the year 2013, in which the principles of adaptation to climate changes will be applied. They will have no more than twenty thousand inhabitants each. These cities will be aimed mainly for pedestrians, and will have a small number of roads, where the speed will be limited to $25 \mathrm{~km} / \mathrm{h}$ (integrated street, with curbs misplaced). For residential buildings will not be provided any parking garage (realized settlements of this type will have 0.7 parking spaces per dwelling). 


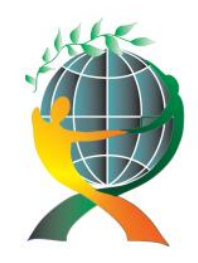

\author{
(online) $=$ ISSN $2285-3642$ \\ ISSN-L = 2285 - 3642 \\ Journal of Economic Development, Environment and People \\ Volume 1, Issue 3, 2012
}

URL: http://iedep.spiruharet.ro

e-mail: office jedep@spiruharet.ro
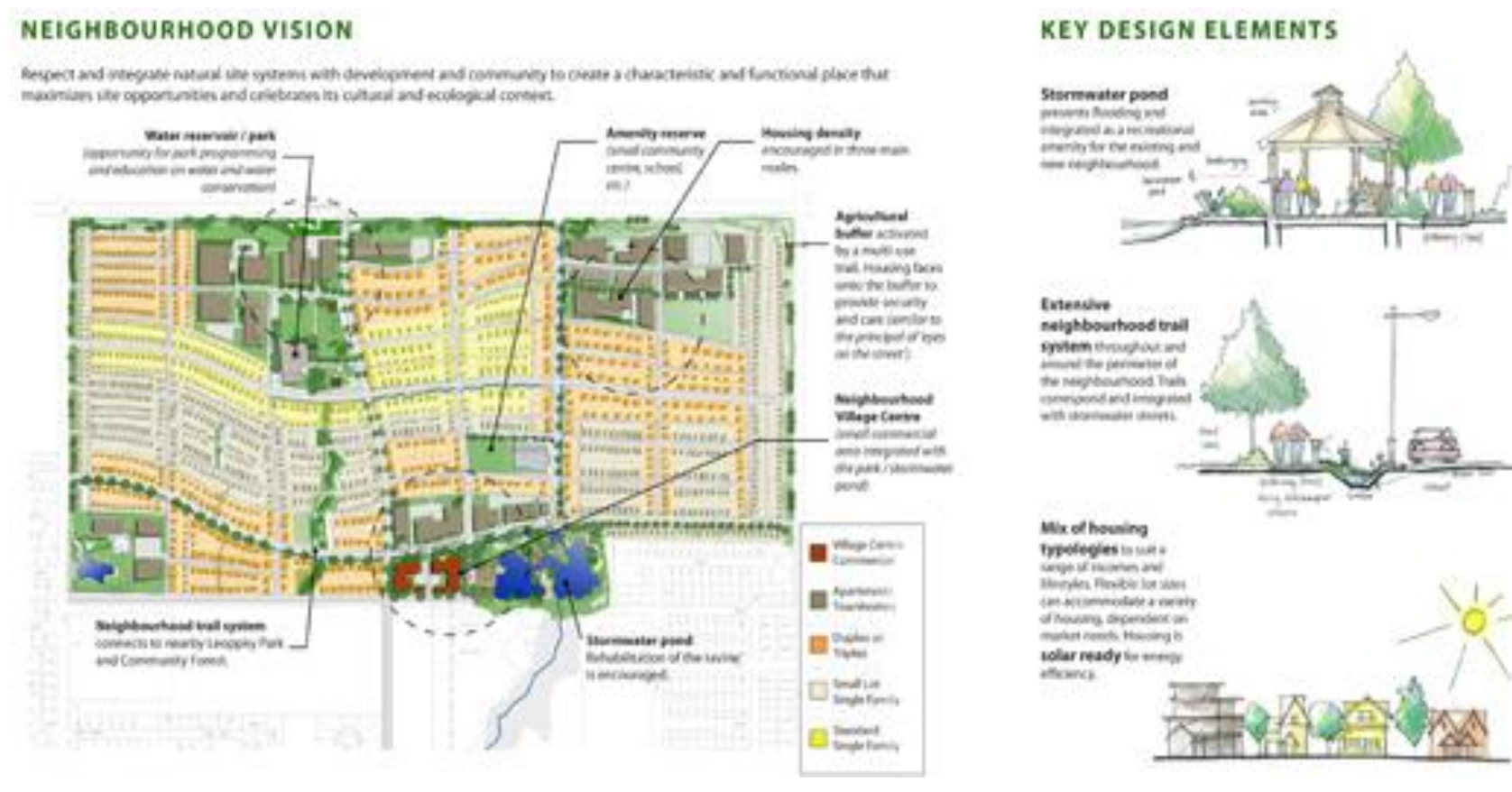

Fig 8: Spatial model display and distribution of activities of new settlements - Dawson Creek Sustainable Neighborhood Plan. All basic facilities will be as far enough AS to reach them can reach on foot (distance up to $500 \mathrm{~m}$ ). The buildings will have good thermal insulation, will be provided BY underground systems for recycling, and most of the energy will provide solar panels, windmills from biomass obtained from local sources. Source: HB Lanark planning and design company presentation http://www.hblanarc.ca/projects/project_details.asp?ProjectID=40

For the example, the $15-20 \mathrm{~cm}$ isolation is applied on the objects of the timber in Malmö. Shutters on the buildings are equipped with solar cells. Each building lot has 0.7 parking spaces per dwelling. A dense network of public transport is provided. Urban planning is supported by networks of small communities that rely on its manufacturing strength and energy (the first stadium of transformation in some countries has already been realized - urban agriculture). "Back to the local activities in almost all aspects of travel and traffic" Modifications of construction vehicles for new forms of energy were required: hydrogen, solar energy, bio-ethanol. 


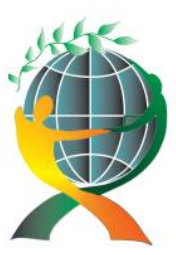

\author{
(online) $=$ ISSN $2285-3642$ \\ ISSN-L = $2285-3642$ \\ Journal of Economic Development, Environment and People \\ Volume 1, Issue 3, 2012
}

URL: http://jedep.spiruharet.ro

e-mail: office jedep@spiruharet.ro
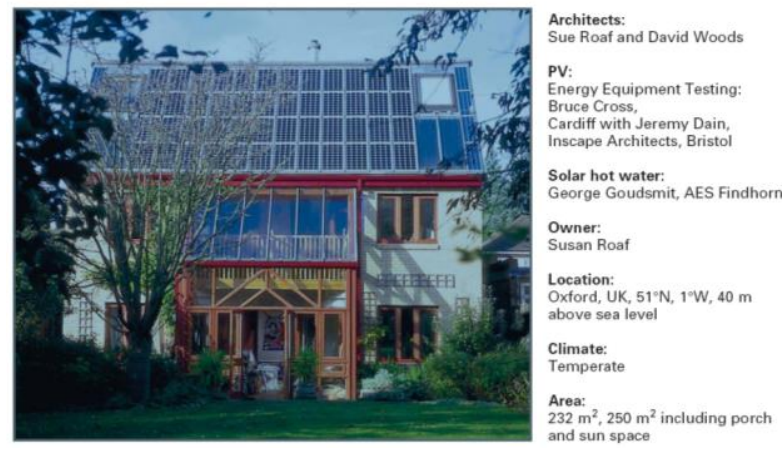

Fig no 9: Resilient dwellings may perform like the Oxford Ecohouse, that has minimal carbon dioxide emissions. Source: Roaf Crichton \& Nicol (2006) ADAPTING BUILDINGS AND CITIES FOR CLIMATE CHANGE: A 21st century survival guide. Burlington: Architectural Press

\title{
3. Conclusions: A recommendations for urban development regulation, their significance and implications for planning in Serbia
}

In order to make the state intervention in urban planning successful, the identification and investigation of problems in the context of climate change is necessary. The recognition the spatial pattern and manifestation of the problem is needed, as well as to identify stakeholders and their responsibilities in the construction, preservation, maintenance and control of natural and created structures. Creative solving problems should be related to the area by establishing precise boundaries - zones, and linked with the values and goals that affect the distribution of activities, construction, preservation and maintenance of natural and created recreation areas and facilities (through a variety of criteria, indicators and parameters).

As a result, the establishing rules and suggestions for activities is expected, in order to timely respond to the forthcoming climate change (includes answers to which stakeholders would take part in investment and control, and when). Also, the rules are expected, regarding the land use and construction of facilities (buildings, the sizes of lots, parking and supply facilities, location and construction of regulation lines, volume of objects, the position of objects on the land and their relation to the water surfaces, the relationship to adjacent structures, parameters of forming building structures, ....). Building standards are also expected (materials for the construction and finishing, color and texture, lighting, landscaping the surrounding area...). The final task is to make practical and technical guidance in the form of illustrations - sketches for its users. 


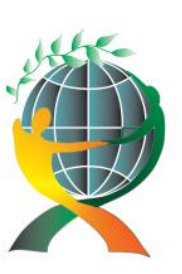

\author{
(online) $=$ ISSN $2285-3642$ \\ ISSN-L = $2285-3642$ \\ Journal of Economic Development, Environment and People \\ Volume 1, Issue 3, 2012
}

URL: http://jedep.spiruharet.ro

e-mail: office jedep@spiruharet.ro
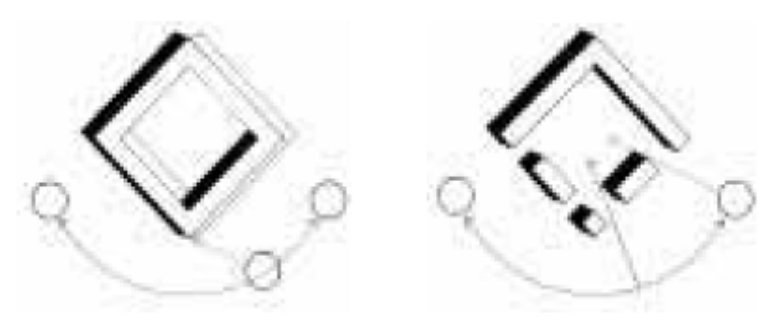

Orientating blocks to the sun's path reduces overshadowed areas within the block

\begin{abstract}
Breaks in the building form or reduced storey heights increase solar penetration of the block
\end{abstract}
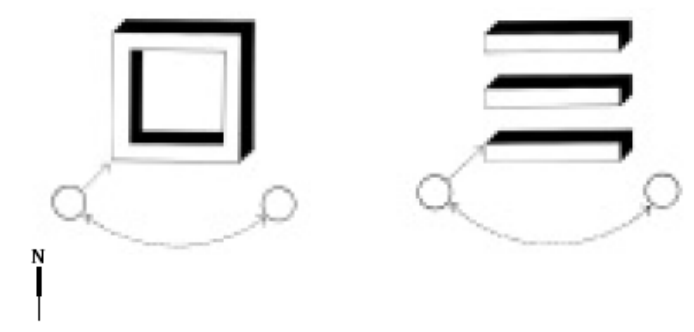

Direction of the sun
South-facing terraces maximise solar gain but can compromise other design objectives

Fig. 10: Dimensions and the block orientation, with the aim of optimal isolation and ventilation Source: Better Places to Live: Creating a movement framework http://www.communities.gov.uk/publications/planningandbuilding/betterplaces

Expected outcomes are in the form of defined action plan, with a precise scheme (timeline) in defining measures for adaptation and protection of areas, assessing and preventing the consequences of climate change. Cooperation between stakeholders in technology transfer, research and information exchange is expected as well.

It is also necessary to presume the types and frequency of activity and its allocation (graph): (accommodation of existing facilities and activities, the terrain, adjusting the soil and water, economic parameters, rules and standards, bioclimatic principles).

In the front line in our battle for survival must be a new generation of resilient buildings, which would use as little energy as possible through good design, provide that energy where possible, from clean, renewable sources that will not pollute nor run out. Defining the rules of construction is needed (the type and distribution of vegetation, orientation, the materialization, regulation, lots, leveling and grouping objects according to bioclimatic principles). The main aims in building refurbishment because of climate change mitigation and adaptation are:

1. To reduce waste in construction, operation and demolition.

2. To be built with goods and materials that produce minimal pollution.

3. Not to destroy fragile biodiversity and ecosystems. 


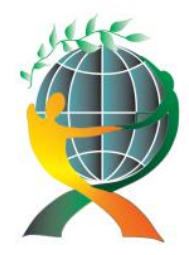

\author{
(online) $=$ ISSN $2285-3642$ \\ ISSN-L = $2285-3642$ \\ Journal of Economic Development, Environment and People \\ Volume 1, Issue 3, 2012 \\ URL: http://jedep.spiruharet.ro \\ e-mail: office jedep@spiruharet.ro
}

4. To apply changes in the consumption mode and supplying electric energy (heating and cooling modes, the geometry of objects, the composition of mantle-envelope objects, etc.)

5. To ensure that people are comfortable, and can survive even in extreme weather within them.

We see non-resilient buildings and settlements all around us that are vulnerable to climate change. Many are already uninsurable, like the hundreds of flood-blighted areas in Serbia, or those already falling prey to the receding river coastlines in 2005. In many homes and offices is simply too hot to sleep, which leads to the increase in climate-related hazards. Those are the problems which will have to be treated properly and solved for a longer time period.

\title{
4. Acknowledgement
}

This paper was realized as a part of the project "Studying climate change and its influence on the environment: impacts, adaptation and mitigation" (43007) financed by the Ministry of Education and Science of the Republic of Serbia within the framework of integrated and interdisciplinary research for the period 2011-2014.

\section{References:}

[1] Bracken, I. (1981) Urban Planning Methods: Research And Policy Analysis. Abingdon: Routledge Library Editions

[2] Dryzek, J (1997) The Politics of Earth. Oxford: Oxford University Press

[3] EU Commission (2007) Adapting to Climate Change in Europe

[4] HB Lanarc planning and design company presentation http://www.hblanarc.ca/projects/project_details.asp?ProjectID=40

[5] Gidens, A. (2008) The Politics of Climate Change. Cambridge: Polity Press

[6] IPPC report AR4 (2007) http://www.ipcc.ch/publications_and_data/publications_and_data_reports.shtml

[7] John Mardaljevich, Institute for energy and Sustainable Development, De Monfort University,Denmark. www.iesd.dmu.ac.dk

[8] Jovanović, S, Savić, S \& Despotović, M (2004) Promene nekih klimatskih parametara u urbanim sredinama Republike Srbije. Kragujevac: Mašinski fakultet

[9] Roaf, Crichton \& Nicol (2006) ADAPTING BUILDINGS AND CITIES FOR CLIMATE CHANGE: A 21st century survival guide. Burlington: Architectural Press 


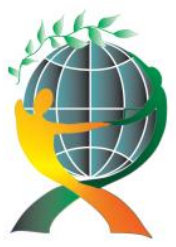

\author{
(online) $=$ ISSN $2285-3642$ \\ ISSN-L = $2285-3642$ \\ Journal of Economic Development, Environment and People \\ Volume 1, Issue 3, 2012 \\ URL: http://jedep.spiruharet.ro \\ e-mail: office jedep@spiruharet.ro
}

[10] Serbian agency for Spatial Development (2010) The Draft of Spatial Plan of the Republic of Serbia 2014 -2021

[11] Simic, I: URBAN BATTERIES - The energy potential of small urban and rural settlements in the region of Vojvodina, IAS-STS Conference 2011, Graz

[12] Stern, N. (2008) Key Elements of a Global Deal on Climate Change. London: London School of Economy

[13] Stiglitz, J. (2004) Ekonomija javnog sektora. Beograd: Ekonomski fakultet

[14] UNEP (1994) The United Nations Framework Convention on Climate Change (UNFCCC)

[15] Vujošević, M. (2004) Racionalnost, legitimitet i implementacija planskih odluka - novije teorijske interpertacijama i pouke za planiranje u Srbiji. Beograd: IAUS 